Jurnal IImiah Pendidikan Matematika Volume 8 No. 3 Tahun 2019

ISSN :2301-9085

\title{
IDENTIFIKASI MISKONSEPSI SISWA SMAN DI KEDIRI MENGGUNAKAN CERTAINTY OF RESPONSE INDEX (CRI) TERMODIFIKASI PADA MATERI TRIGONOMETRI
}

\author{
Putri Aprilita Dina \\ Pendidikan Matematika, FMIPA, Universitas Negeri Surabaya, e-mail: putridina@mhs.unesa.ac.id \\ Abdul Haris Rosyidi \\ Pendidikan Matematika, FMIPA, Universitas Negeri Surabaya, e-mail: abdulharis@unesa.ac.id
}

\begin{abstract}
Abstrak
Tidak semua konsep dapat dipahami siswa dengan baik, sehingga pemahaman siswa kurang dan menyebabkan siswa mengalami miskonsepsi. Miskonsepsi adalah kesalahan terhadap pemahaman suatu konsep tertentu. Untuk mengidentifikasi miskonsepsi menggunakan Certainty of Response Index (CRI) termodifikasi yang terdiri dari soal pilihan ganda, alasan terbuka, tingkat keyakinan, dan alasan memilih tingkat keyakinan. Penelitian deskriptif ini bertujuan untuk mendeskripsikan miskonsepsi siswa laki-laki dan perempuan di SMAN Kediri menggunakan CRI termodifikasi pada materi perbandingan trigonometri pada segitiga siku-siku. Subjek penelitian ini adalah 202 siswa yang terdiri dari 80 siswa siswa laki-laki dan 102 siswa perempuan yang diambil dari tiga sekolah yang berbeda yaitu di SMAN 2, SMAN 3, dan SMAN 6 Kediri. Hasil penelitian menunjukkan bahwa miskonsepsi yang dialami siswa laki-laki yaitu pengurangan pecahan, mengubah informasi verbal ke bentuk visual, menentukan panjang sisi segitiga, mendefinisikan tangen, bentuk pecahan akar, menentukan sisi depan sudut, penjumlahan akar, dan mendefinisikan sinus. Miskonsepsi yang dialami siswa perempuan yaitu mendefinisikan tangen, mengubah informasi verbal ke bentuk visual, dan bentuk pecahan akar.
\end{abstract}

Kata Kunci: Miskonsepsi, Certainty of Response Index (CRI) termodifikasi, trigonometri, jenis kelamin.

\begin{abstract}
Not all concepts can be understood by students well, so that students' understanding is lacking and causes students to experience misconceptions. Misconception is an error in understanding a particular concept. Misconceptions using a modified Certainty of Response Index (CRI) consisting of multiple choice questions, open reasons, levels of confidence, and reasons for choosing a level of confidence. This descriptive study aims to describe the misconceptions of male and female students in Kediri using a modified CRI on trigonometric comparison material on right triangles. The subject of this study were 202 students consisting of 80 male students and 102 female students taken from three different school, namely in SMAN 2, SMAN 3 , and SMAN 6 Kediri. The result showed that the misconceptions experienced by male students were fraction reduction, changing verbal information into visual forms, determine the length of the side of the triangle, defining tangents, fractional forms, determine the front side of the corner, summarizing roots, and defining sine. Misconceptions experienced by female students are defining tangents, changing verbal information into visual forms, and forms of fractional roots.
\end{abstract}

Keywords: Misconception, modified Certainty of Response Index (CRI), trigonometry, gender.

\section{PENDAHULUAN}

Matematika merupakan salah satu bidang yang berperan penting dalam pendidikan. Hal ini dapat dilihat bahwa matematika merupakan salah satu mata pelajaran wajib yang ada di sekolah baik di sekolah dasar, sekolah menengah pertama, maupun sekolah menengah atas (Permendikbud No. 59 Tahun 2014), ditetapkannya matematika sebagai salah satu mata pelajaran pokok/ wajib dalam setiap Ujian Akhir Nasional (UAN) (Permendikbud No. 21 Tahun 2016), dan dilihat dari jumlah jam mata pelajaran matematika yang lebih banyak (Permendikbud No. 59 Tahun 2014).

Soedjadi (2000: 110) berpendapat bahwa "konsep adalah ide abstrak yang dapat digunakan untuk menggolongkan atau mengklasifikasikan sekumpulan objek." Konsep dalam matematika tersusun secara 
hierarkis, logis, dan sistematis (Ramadhan, dkk, 2017). Hal tersebut berarti konsep-konsep dalam matematika saling berkaitan satu dengan yang lain dimulai dari konsep yang sederhana menuju konsep yang kompleks. Terkadang suatu konsep menjadi prasyarat konsep yang lain, sehingga siswa harus mampu memahami suatu konsep dengan baik agar saat belajar konsep berikutnya lebih mudah.

Tujuan pembelajaran matematika pada kurikulum jenjang pendidikan dasar dan menengah yaitu memahami konsep matematika, menjelaskan keterkaitan antar konsep dan mengaplikasikan konsep atau algoritma secara luwes, akurat, efisien, dan tepat dalam pemecahan masalah (Permendikbud No. 59 Tahun 2014). Hal ini menunjukkan betapa pentingnya pengetahuan konsep pada pembelajaran matematika.

Dalam proses pembelajaran, siswa dituntut untuk membangun konsep mereka sendiri berdasarkan pemahaman siswa sebelumnya agar siswa dapat mengetahui cara menemukan suatu konsep, konsep tersebut ada kaitannya dengan konsep yang diperoleh siswa sebelumnya. Konsep awal yang dimiliki seseorang tentang suatu objek disebut prakonsepsi (Soedjadi, 2000). Jika konsep awal yang diterima seseorang berbeda dengan konsep yang baru ia terima, maka keadaan tersebut merupakan prakonsepsi berubah menjadi miskonsepsi (Soedjadi, 2000). Jika siswa tidak memahami konsep dengan baik, maka siswa tersebut akan mengalami kesulitan untuk belajar konsep berikutnya. Kurangnya pemahaman konsep siswa menyebabkan siswa salah memahami dari suatu konsep. Hal ini dapat membuat siswa mengalami miskonsepsi.

Menurut Li dan Li (2008) kesalahan disebabkan oleh kecerobohan, algoritma yang salah, dan miskonsepsi. Li dan Li (2008) miskonsepsi adalah kesalahan terhadap pemahaman konsep dasar tertentu. Dari pendapat tersebut, miskonsepsi merupakan kesalahan dan kesalahan belum tentu miskonsepsi.

Mengidentifikasi miskonsepsi siswa sangat penting bagi seorang guru, karena guru dapat memperbaiki miskonsepsi tersebut, sehingga siswa tidak lagi mengalami miskonsepsi. Lebih baik lagi jika seorang guru mengetahui miskonsepsi siswa sejak awal, sehingga guru dapat segera memperbaiki miskonsepsi siswa sebelum lanjut ke konsep berikutnya. Penelitian tentang miskonsepsi ini juga penting untuk dikembangkan guna mengetahui keberhasilan pembelajaran konsep yang telah dilakukan (Nugraeni, 2013).

Untuk mengidentifikasi miskonsepsi siswa dapat menggunakan Certainty of Response Index (CRI) yang diperkenalkan oleh Hasan, et al (1999). Instrumen ini terdiri dari dua bagian, bagian pertama yaitu pertanyaan tentang konsep dan bagian kedua yaitu untuk mengetahui tingkat keyakinan respon ketika menjawab konsep. Dengan instrumen ini ada tiga kategori respon terhadap pertanyaan konsep yaitu paham konsep, miskonsepsi, dan tidak paham konsep.

Hakim, et al (2012) melakukan teknik modifikasi CRI yaitu identifikasi miskonsepsi siswa dengan meminta alasan terbuka selain jawaban dan skala CRI. Teknik ini didasarkan pada karakter siswa di Indonesia yang cenderung tidak yakin dengan jawaban mereka.

Berdasarkan hasil penelitian Malikha dan Amir (2018) menunjukkan bahwa Hasil penelitian Mufidah dan Budiarto (2018) menunjukkan bahwa Hasil penelitian Sarlina (2015) menunjukkan bahwa Berdasarkan penelitian-penelitian di atas, masih ada miskonsepsi yang terjadi pada siswa baik pada siswa SD, SMP, maupun SMA pada mata pelajaran matematika, sehingga perlu untuk mengetahui miskonsepsi siswa pada materi matematika yang lainnya.

Salah satu materi matematika yang diyakini oleh siswa sangat sulit dan abstrak jika dibandingkan materi matematika yang lainnya yaitu trigonometri (Gur, 2009). Berdasarkan laporan hasil Ujian Nasional BSNP PUSPENDIK mengenai persentase penguasaan materi soal Ujian Nasional tahun pelajaran 2017/2018 terhadap materi geometri dan trigonometri pada tiga tahun terakhir masih rendah. Hal ini menunjukkan bahwa ada siswa yang belum memahami konsep trigonometri dengan baik. Mereka masih beranggapan bahwa matematika merupakan pelajaran yang penuh rumus-rumus dan ilmu pasti, sehingga mereka hanya mementingkan penghafalan rumus.

Setiap siswa memiliki tingkat kemampuan yang berbeda-beda. Salah satu faktor yang memengaruhi kemampuan matematika yaitu jenis kelamin. Berdasarkan penelitian Rahim (2015) yang menunjukkan bahwa siswa laki-laki cenderung memiliki pemahaman yang cukup baik dalam belajar matematika dibanding dengan siswa perempuan. Sedangkan menurut Tadda (2015) menunjukkan bahwa kesalahan yang paling banyak dilakukan oleh siswa baik siswa laki-laki maupun perempuan adalah sama. Berdasarkan pendapat dan penelitian yang telah dilakukan tentang perbedaan jenis kelamin yang hasilnya berbeda-beda, maka peneliti tertarik untuk melakukan penelitian tentang miskonsepsi ditinjau dari perbedaan jenis kelamin.

Berdasarkan uraian tersebut, peneliti tertarik untuk melakukan penelitian tentang miskonsepsi dengan judul "Identifikasi Miskonsepsi Siswa SMAN di Kediri Menggunakan Certainty of Response Index (CRI) Termodifikasi pada Materi Trigonometri”.

\section{METODE}

Jenis penelitian ini adalah penelitian deskriptif tentang gambaran mengenai miskonsepsi yang dialami siswa lakilaki maupun perempuan dan jumlah kuantitas siswa lakilaki maupun perempuan yang miskonsepsi pada materi trigonometri di SMAN Kediri. Penelitian ini dilaksanakan di tiga sekolah yang berbeda berdasarkan hasil UN matematika pada tahun ajaran 2017/2018. Sekolah tersebut yaitu SMAN 2 Kediri (tinggi), SMAN 3 Kediri (sedang) dan SMAN 6 Kediri (rendah). Subjek dalam penelitian ini yaitu 202 siswa yang terdiri dari 80 siswa laki-laki dan 102 siswa perempuan kelas X tahun ajaran 2018/2019 yang diambil dari 3 sekolah berbeda tersebut. 
Instrumen yang digunakan pada penelitian ini adalah tes dan peneliti sebagai pembuat instrumen. Tes miskonsepsi ini terdiri dari 4 soal pilihan ganda, alasan terbuka, tingkat keyakinan siswa, dan alasan memilih tingkat keyakinan. Instrumen tes diadaptasi dari soal-soal UN matematika 2017/2018. Teknik analisis data dimulai dengan analisis data hasil tes miskonsepsi. selanjutnya pengelompokan data berdasarkan tabel 1 berikut.

Tabel 1. Kriteria untuk membedakan siswa yang paham konsep, miskonsepsi, dan tidak paham konsep dengan teknik CRI termodifikasi

\begin{tabular}{|c|c|c|c|}
\hline $\begin{array}{c}\text { Answer } \\
\text { (Pilihan } \\
\text { Jawaban) }\end{array}$ & $\begin{array}{c}\text { Reason } \\
\text { (Alasan) }\end{array}$ & $\begin{array}{c}\text { CRI } \\
\text { value } \\
\text { (Nilai } \\
\text { CRI) }\end{array}$ & $\begin{array}{c}\text { Description } \\
\text { (Kategori) }\end{array}$ \\
\hline $\begin{array}{l}\text { True } \\
\text { (Benar) }\end{array}$ & $\begin{array}{l}\text { True } \\
\text { (Benar) }\end{array}$ & $>2,5$ & $\begin{array}{l}\text { Understand the } \\
\text { concept of well } \\
\text { (Paham Konsep) }\end{array}$ \\
\hline $\begin{array}{l}\text { True } \\
\text { (Benar) }\end{array}$ & $\begin{array}{l}\text { True } \\
\text { (Benar) }\end{array}$ & $<2,5$ & $\begin{array}{l}\text { Understand the } \\
\text { concept but are } \\
\text { not confident } \\
\text { with the answers } \\
\text { given (Paham } \\
\text { Konsep tetapi } \\
\text { tidak yakin } \\
\text { dengan } \\
\text { jawabannya) }\end{array}$ \\
\hline $\begin{array}{l}\text { True } \\
\text { (Benar) }\end{array}$ & $\begin{array}{l}\text { False } \\
\text { (Salah) }\end{array}$ & $>2,5$ & $\begin{array}{l}\text { Misconceptions } \\
\text { (Miskonsepsi) }\end{array}$ \\
\hline $\begin{array}{l}\text { True } \\
\text { (Benar) }\end{array}$ & $\begin{array}{l}\text { False } \\
\text { (Salah) }\end{array}$ & $<2,5$ & $\begin{array}{l}\text { Do not know the } \\
\text { concept } \\
\text { (Tidak Paham } \\
\text { Konsep) }\end{array}$ \\
\hline $\begin{array}{l}\text { False } \\
\text { (Salah) }\end{array}$ & $\begin{array}{l}\text { True } \\
\text { (Benar) }\end{array}$ & $>2,5$ & $\begin{array}{l}\text { Misconceptions } \\
\text { (Miskonsepsi) }\end{array}$ \\
\hline $\begin{array}{l}\text { False } \\
\text { (Salah) }\end{array}$ & $\begin{array}{l}\text { True } \\
\text { (Benar) }\end{array}$ & $<2,5$ & $\begin{array}{l}\text { Do not know the } \\
\text { concept } \\
\text { (Tidak Paham } \\
\text { Konsep) }\end{array}$ \\
\hline $\begin{array}{l}\text { False } \\
\text { (Salah) }\end{array}$ & $\begin{array}{l}\text { False } \\
\text { (Salah) }\end{array}$ & $>2,5$ & $\begin{array}{l}\text { Misconceptions } \\
\text { (Miskonsepsi) }\end{array}$ \\
\hline $\begin{array}{l}\text { False } \\
\text { (Salah) }\end{array}$ & $\begin{array}{l}\text { False } \\
\text { (Salah) }\end{array}$ & $<2,5$ & $\begin{array}{l}\text { Do not know the } \\
\text { concept } \\
\text { (Tidak Paham } \\
\text { Konsep) }\end{array}$ \\
\hline
\end{tabular}

(Sumber: Hakim, et al, 2012)

Dengan tabulasi indeks CRI pada jawaban siswa maka akan diketahui siswa-siswa yang paham konsep, paham konsep tidak yakin, miskonsepsi, tidak paham konsep. Subjek dapat dikategorikan berdasarkan per soal.
Jika ada komponen (pilihan ganda, alasan terbuka, dan tingkat keyakinan) yang tidak terjawab, maka siswa tidak dapat dikategorikan ke dalam semua kategori. Jika alasan siswa salah dalam perhitungan, maka siswa tidak dapat dikategorikan berdasarkan tabel 1. Analisis yang terkahir yaitu perhitungan data menurut Sudijono (2009) sebagai berikut.

$p=\frac{f}{n} \times 100 \%$

Keterangan:

$f=$ frekuensi yang sedang dicari persentasenya

$N=$ number of cases (jumlah frekuensi/ banyak individu)

$P=$ angka persentase

\section{HASIL DAN PEMBAHASAN}

Berdasarkan hasil tes miskonsepsi diperoleh banyak siswa laki-laki dan perempuan yang mengalami miskonsepsi sebagai berikut.

Tabel 2. Data dan persentase banyak siswa laki-laki dan perempuan yang mengalami miskonsepsi

\begin{tabular}{|c|c|c|}
\hline $\begin{array}{c}\text { Soal } \\
\text { No. }\end{array}$ & $\begin{array}{c}\text { Banyak siswa } \\
\text { laki-laki }\end{array}$ & $\begin{array}{c}\text { Banyak siswa } \\
\text { perempuan }\end{array}$ \\
\hline 1. & $1(1,25 \%)$ & $0(0,00 \%)$ \\
\hline 2. & $4(5,00 \%)$ & $2(1,96 \%)$ \\
\hline 3. & $7(8,75 \%)$ & $3(2,94 \%)$ \\
\hline 4. & $3(3,75 \%)$ & $2(1,96 \%)$ \\
\hline
\end{tabular}

Berdasarkan analisis hasil data tes miskonsepsi, siswa lakilaki maupun perempuan mengalami miskonsepsi yang berbeda-beda. Berikut miskonsepsi yang dialami siswa laki-laki maupun perempuan.

\section{Miskonsepsi yang dialami siswa laki-laki}

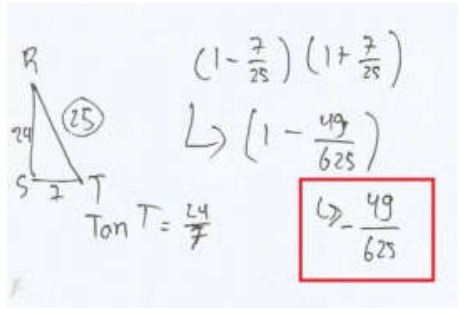

Gambar 1. Jawaban siswa laki-laki miskonsepsi pengurangan pecahan

Siswa dapat mengubah informasi verbal ke bentuk visual dengan benar, sehingga siswa dapat menentukan sisi-sisi dari segitiga siku-siku dengan benar yaitu 7, 24, dan 25. Kemudian siswa dapat menentukan $\cos T$ dan $\sin R$ dengan benar yaitu $\frac{7}{25}$. Namun, siswa salah ketika menentukan hasil dari $\left(1 \frac{49}{625}\right)$. Siswa tidak salah menghitung, tetapi siswa beranggapan bahwa $\left(\begin{array}{ll}1 & \frac{49}{625}\end{array}\right)=$ 
$\frac{49}{625}$ sama seperti konsep $0 \quad a=a$, sehingga siswa
memilih pilihan jawaban $\frac{49}{625}$

Siswa tersebut memilih pilihan jawaban yang salah yaitu B. $\frac{49}{625}$ dan menuliskan alasan dengan salah yaitu ketika $\left(1 \frac{49}{625}\right)=\frac{49}{625}$ Untuk tingkat keyakinan siswa yaitu 4. Tingkat keyakinan tersebut merupakan tingkat keyakinan yang tinggi. Dari penjelasan tersebut, pilihan jawaban salah, alasan salah, tingkat keyakinan tinggi, maka siswa dapat dikategorikan sebagai siswa yang mengalami miskonsepsi pada pengurangan pecahan.

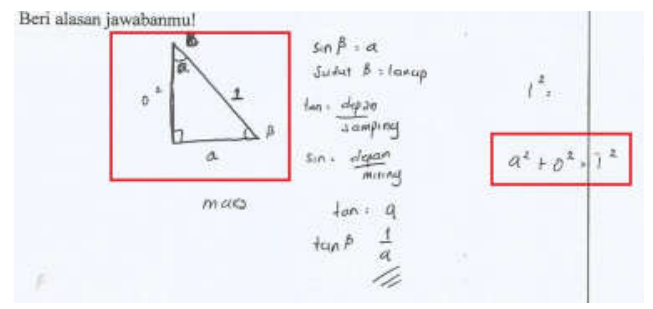

Gambar 2. Jawaban siswa laki-laki miskonsepsi mengubah informasi verbal ke bentuk visual dan menentukan panjang sisi segitiga

Satu siswa menuliskan apa yang diketahui yaitu $\sin \beta=a$ dan siswa menuliskan $\sin =\frac{\text { depan }}{\text { miring }}$, hal ini menunjukkan bahwa siswa memahami konsep sinus yaitu perbandingan sisi depan dan sisi miring. Siswa juga memahami konsep tangen yang ditunjukkan oleh siswa ketika menuliskan $\tan =\frac{\text { depan }}{\text { samping }}$. Namun, siswa salah ketika mengubah informasi verbal ke bentuk visual, sehingga siswa tidak dapat menggambarkan komponen sudut dan panjang sisi pada segitiga siku-siku dengan benar. Oleh karena itu, siswa beranggapan bahwa panjang sisi samping dari sudut $\beta$ yaitu $a$ dan sisi miring yaitu 1 . Untuk menentukan sisi depan dari sudut $\beta$ menggunakan phytagoras dan siswa beranggapan bahwa $a^{2}+0^{2}=1^{2}$. Hal ini disebabkan karena siswa beranggapan bahwa sisi miring dari segitiga adalah 1 dan sisi-sisi lainnya pasti kurang dari 1, sehingga siswa menentukan sisi depan dari sudut $\beta$ yaitu $0^{2}$. Karena siswa salah ketika mengubah informasi verbal ke bentuk visual, salah ketika menentukan panjang sisi segitiga, dan pilihan jawaban yang tersedia menurut siswa benar maka siswa memilih pilihan jawaban $\frac{1}{a}$.

Siswa tersebut memilih pilihan jawaban yang salah yaitu E. $\frac{1}{a}$ dan menuliskan alasan yang salah yaitu mengubah informasi verbal ke bentuk visual. Untuk tingkat keyakinan siswa yaitu 3. Tingkat keyakinan tersebut merupakan tingkat keyakinan yang tinggi. Dari penjelasan tersebut, pilihan jawaban salah, alasan salah, tingkat keyakinan tinggi, maka siswa dapat dikategorikan sebagai siswa yang mengalami miskonsepsi mengubah informasi verbal ke bentuk visual dan menentukan sisi panjang segitiga.

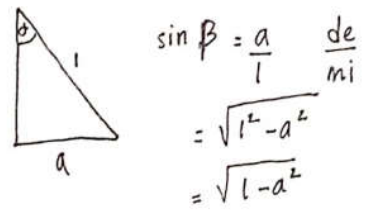

\section{Gambar 3. Jawaban siswa laki-laki miskonsepsi ketika mendefinisikan tangen}

Siswa menuliskan apa yang diketahui yaitu $\sin \beta=$ $\frac{a}{1}=\frac{\text { depan }}{\text { miring }}$, hal ini menunjukkan bahwa siswa memahami konsep dari sinus dan dapat mengubah informasi verbal ke bentuk visual, sehingga siswa dapat menentukan sisi depan dari sudut $\beta$ yaitu $a$ dan sisi miring segitiga yaitu 1 . Namun siswa tidak menuliskan konsep tangen dan tidak menentukan sisi samping dari sudut $\beta$. Siswa langsung menuliskan $\sqrt{1 a^{2}}$ dan siswa menganggap $\sqrt{1 a^{2}}$ merupakan jawaban yang tepat.

Siswa tersebut memilih pilihan jawaban yang salah yaitu B. $\sqrt{1 \quad a^{2}}$ dan menuliskan alasan yang salah yaitu $=\sqrt{1 a^{2}}$. Untuk tingkat keyakinan siswa yaitu 3 . Tingkat keyakinan tersebut merupakan tingkat keyakinan yang tinggi. Dari penjelasan tersebut, pilihan jawaban salah, alasan salah, dan tingkat keyakinan tinggi, maka siswa dapat dikategorikan sebagai siswa yang mengalami miskonsepsi mendefinisikan tangen.

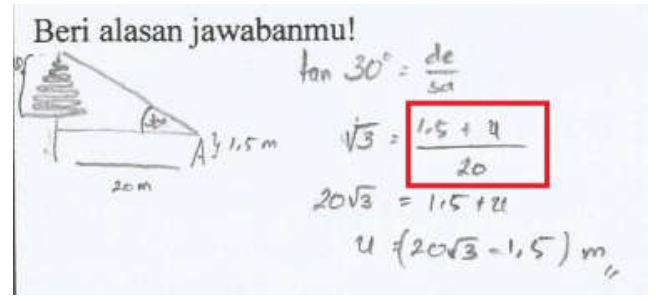

Gambar 4. Jawaban siswa laki-laki miskonsepsi ketika menentukan sisi depan sudut

Siswa dapat mengubah informasi verbal ke bentuk visual dengan benar dan dapat menggambarkan komponen sudut dan panjang sisi pada segitiga siku-siku. Siswa juga menuliskan $\tan 30^{\circ}=\frac{\text { depan }}{\text { samping }}$, hal ini berarti siswa memahami konsep tangen yaitu perbandingan sisi depan dan sisi samping sudut $30^{\circ}$. Siswa salah ketika menentukan nilai $\tan 30^{\circ}$. Siswa juga salah ketika menentukan sisi depan dari sudut $30^{\circ}$. Siswa beranggapan bahwa sisi depan dari sudut $30^{\circ}$ yaitu $1,5+x$, sehingga ketika menentukan $x$ hasil akhirnya yaitu $20 \sqrt{3}$ dikurangi 1,5. Karena salah ketika menentukan sisi depan dari sudut, maka siswa memilih pilihan jawaban $20 \sqrt{3} \quad 1,5$.

Siswa memilih pilihan jawaban yang salah yaitu D. $(20 \sqrt{3}$ 1,5) $m$. Siswa salah ketika menuliskan alasan yaitu ketika menentukan sisi depan dari sudut $30^{\circ}$. Untuk tingkat keyakinan siswa yaitu 4. Tingkat keyakinan tersebut merupakan tingkat keyakinan tinggi. Dari penjelasan tersebut, pilihan jawaban salah, alasan salah, 
dan tingkat keyakinan tinggi, maka siswa dapat dikategorikan sebagai siswa yang mengalami miskonsepsi menentukan sisi depan dari sudut.

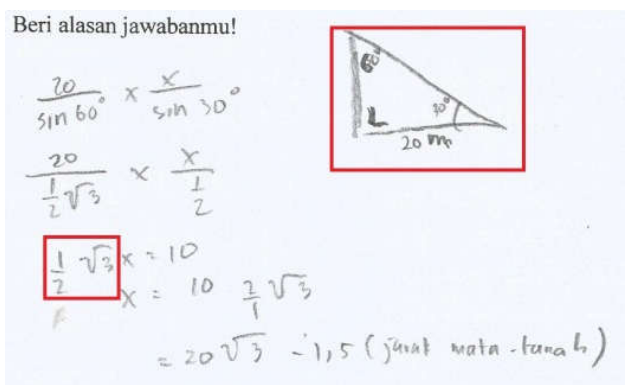

Gambar 5. Jawaban siswa laki-laki miskonsepsi ketika mengubah informasi verbal ke bentuk visual dan bentuk pecahan akar

Siswa dapat menggambarkan komponen sudut dan panjang sisi pada segitiga siku-siku berdasarkan soal yang diketahui, sehingga siswa dapat menentukan sisi depan dari sudut $30^{\circ}$ dengan menggunakan konsep aturan sinus. Namun, siswa salah ketika menentukan $x$. Siswa beranggapan bahwa $\frac{10}{\frac{1}{2} \sqrt{3}}=20 \sqrt{3}$. Hal ini disebabkan siswa beranggapan bahwa $\frac{1}{2} \sqrt{3}$ berbeda dengan $\frac{\sqrt{3}}{2}$, sehingga ketika $\frac{10}{\frac{1}{2} \sqrt{3}}=10.2 \sqrt{3}=20 \sqrt{3}$. Siswa salah ketika mengubah informasi verbal ke bentuk visual, sehingga siswa tidak dapat menentukan tinggi pohon cemara dengan benar. Karena kesalahan tersebut menyebabkan siswa beranggapan bahwa untuk menentukan tinggi pohon cemara sama dengan $20 \sqrt{3}$ dikurangi 1,5 (jarak Andika dengan tanah). Oleh karena itu siswa memilih pilihan jawaban $(20 \sqrt{3} \quad 1,5) m$.

Siswa tersebut memilih pilihan jawaban yang salah yaitu D. $(20 \sqrt{3} \quad 1,5) m$. Siswa menuliskan alasan yang salah yaitu ketika mengubah informasi verbal ke bentuk visual dan bentuk pecahan akar. Untuk tingkat keyakinan siswa berkisar 3. Tingkat keyakinan tersebut merupakan tingkat keyakinan yang cukup tinggi. Dari penjelasan tersebut, pilihan jawaban salah, alasan salah, tingkat keyakinan tinggi, maka siswa dapat dikategorikan sebagai siswa yang mengalami miskonsepsi mengubah informasi verbal ke bentuk visual dan bentuk pecahan akar.

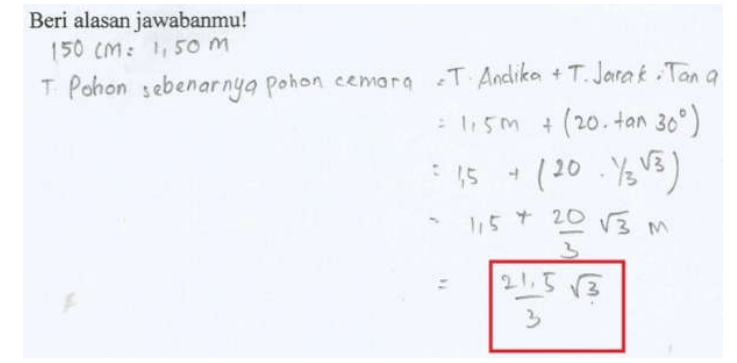

Gambar 6. Jawaban siswa laki-laki miskonsepsi ketika penjumlahan akar
Siswa menuliskan apa yang diketahui yaitu $150 \mathrm{~cm}=1,50 \mathrm{~m}$. Konsep yang digunakan siswa untuk menentukan tinggi pohon cemara sudah benar yaitu tinggi pohon cemara sama dengan hasil kali jarak dengan tan $30^{\circ}$ ditambahkan tinggi Andika. Siswa salah ketika penjumlahan akar. Siswa tidak salah menghitung, tetapi siswa salah pemahaman terhadap penjumlahan. Siswa beranggapan bahwa $\frac{20}{3} \sqrt{3}+1,5$ dapat dijumlahkan, sehingga siswa memilih pilihan jawaban $\frac{21,5}{3} \sqrt{3}$.

Siswa tersebut memilih pilihan jawaban yang salah yaitu B. $\left(\frac{21,5}{3} \sqrt{3}\right) m$ dan menuliskan alasan yang salah yaitu $\frac{20}{3} \sqrt{3}+1,5=\frac{21,5}{3} \sqrt{3}$. Untuk tingkat keyakinan siswa 3 dan 5. Tingkat keyakinan tersebut merupakan tingkat keyakinan tinggi. Dari penjelasan tersebut, pilihan jawaban salah, alasan salah, dan tingkat keyakinan tinggi, maka siswa dapat dikategorikan sebagai siswa yang mengalami miskonsepsi pada penjumlahan akar.

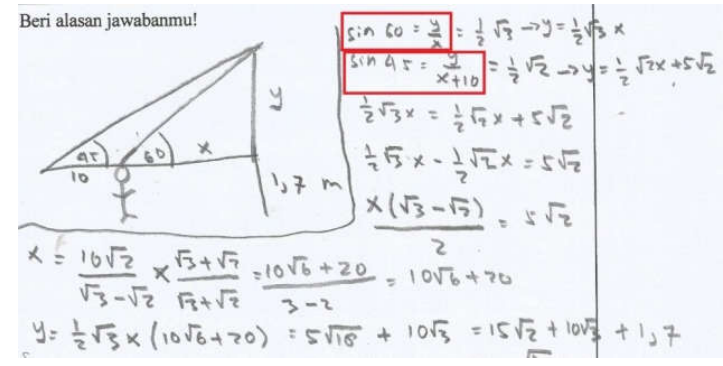

\section{Gambar 7. Jawaban siswa laki-laki miskonsepsi ketika mendefinisikan sinus}

Siswa dapat mengubah informasi verbal ke bentuk visual dengan benar, sehingga siswa dapat menggambarkan komponen sudut dan panjang sisi pada segitiga siku-siku dengan benar. Siswa juga dapat menyelesaikan permasalahan dengan konsep yang benar yaitu dengan menggunakan konsep substitusi. Untuk hasil akhirnya, siswa tidak menemukan jawabannya pada pilihan jawaban, sehingga siswa memilih pilihan jawaban yang paling mendekati dengan jawaban siswa. Oleh karena itu siswa memilih pilihan jawaban $16,7+10 \sqrt{3}$. Namun dari jawaban siswa, ada kesalahan yang siswa tidak sadari, yaitu $\sin 60^{\circ}=\frac{y}{x}$ dan $\sin 45^{\circ}=\frac{y}{x+10}$. Dari gambar segitiga yang dibuat oleh siswa menunjukkan bahwa $y$ merupakan sisi depan dari sudut $60^{\circ}$ dan $x$ merupakan sisi samping dari sudut $60^{\circ}$ dan dari jawaban $\operatorname{siswa} \sin 60^{\circ}=\frac{y}{x}$, hal ini menunjukkan bahwa siswa salah pemahaman tentang konsep sinus.

Siswa tersebut memilih pilihan jawaban yang salah yaitu E. $(16,7+10 \sqrt{3}) m$ dan menuliskan alasan yang salah yaitu ketika mendefiniskan sinus. Untuk tingkat keyakinan siswa yaitu 4. Tingkat keyakinan tersebut merupakan tingkat keyakinan yang cukup tinggi. Dari penjelasan tersebut, pilihan jawaban salah, alasan salah, dan tingkat keyakinan tinggi, maka siswa dapat 
dikategorikan sebagai siswa yang mengalami miskonsepsi pada definisi sinus.

\section{Miskonsepsi yang dialami siswa perempuan}

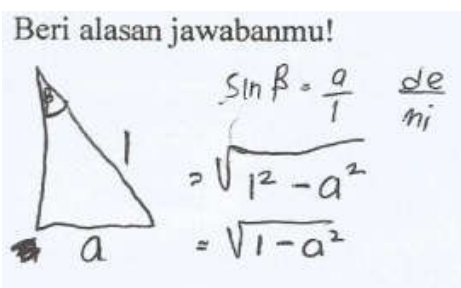

Gambar 7. Jawaban siswa perempuan miskonsepsi ketika mendefinisikan tangen

Siswa menuliskan apa yang diketahui yaitu $\sin \beta=$ $\frac{a}{1}=\frac{\text { depan }}{\text { miring }}$. Siswa juga dapat mengubah informasi verbal ke bentuk visual, sehingga dapat menentukan sisi depan dari sudut $\beta$ yaitu $a$ dan sisi miring yaitu 1. Namun siswa tidak menuliskan konsep tangen dan tidak menentukan sisi samping dari sudut $\beta$. Siswa langsung menuliskan $\sqrt{1 a^{2}}$ dan mengganggap $\sqrt{1 a^{2}}$ merupakan jawaban yang tepat. Oleh karena itu siswa memilih pilihan jawaban $\sqrt{1 a^{2}}$.

Siswa memilih pilihan jawaban yang salah yaitu B. $\sqrt{1 a^{2}}$. Siswa menuliskan alasan yang salah yaitu $=$ $\sqrt{1 \quad a^{2}}$. Untuk tingkat keyakinan siswa berkisar 5 . Tingkat keyakinan tersebut merupakan tingkat keyakinan yang tinggi. Dari penjelasan tersebut, pilihan jawaban salah, alasan salah, dan tingkat keyakinan tinggi, maka siswa dapat dikategorikan sebagai siswa yang mengalami miskonsepsi mendefinisikan tangen.

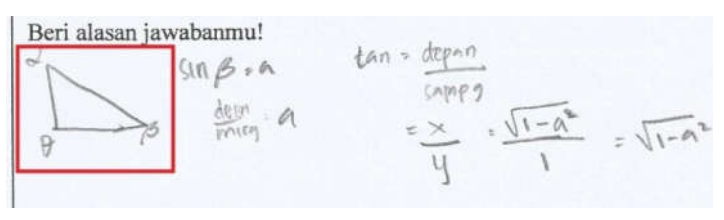

Gambar 8. Jawaban siswa perempuan miskonsepsi ketika mengubah informasi verbal ke bentuk visual

Siswa menuliskan apa yang diketahui yaitu $\sin \beta=$ $a=\frac{\text { depan }}{\text { miring }}$, hal ini menunjukkan bahwa siswa memahami konsep sinus dengan benar. Siswa juga menuliskan $\tan =$ $\frac{\text { depan }}{\text { samping }}$, hal ini menunjukkan bahwa siswa memahami dari konsep tangen yaitu perbandingan sisi depan dan sisi samping sudut. Namun, siswa salah ketika mengubah informasi verbal ke bentuk visual, sehingga siswa tidak dapat menggambarkan komponen sudut dan panjang sisi pada segitiga siku-siku dengan benar. Akibatnya siswa tidak dapat menentukan sisi depan, sisi samping, dan sisi miring dari segitiga siku-siku dengan benar. Siswa menuliskan $\frac{\sqrt{1-a^{2}}}{1}$, hal ini berarti siswa beranggapan bahwa $\sqrt{1 a^{2}}$ merupakan sisi depan dari sudut $\beta$ dan 1 merupakan sisi samping dari sudut $\beta$. Oleh karena itu siswa memilih pilihan jawaban $\sqrt{1 a^{2}}$.

Siswa memilih pilihan jawaban yang salah yaitu B. $\sqrt{1 a^{2}}$ dan menuliskan alasan yang salah yaitu mengubah informasi verbal ke bentuk visual. Untuk tingkat keyakinan siswa yaitu 3. Tingkat keyakinan tersebut merupakan tingkat keyakinan tinggi. Dari penjelasan tersebut, pilihan jawaban salah, alasan salah, dan tingkat keyakinan tinggi, maka siswa dapat dikategorikan sebagai siswa yang mengalami miskonsepsi pada mengubah informasi verbal ke bentuk visual.

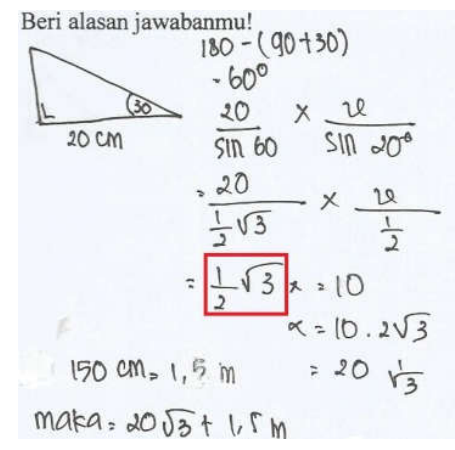

Gambar 9. Jawaban siswa perempuan miskonsepsi ketika bentuk pecahan akar

Siswa dapat mengubah informasi verbal ke bentuk visual dengan benar, sehingga siswa dapat menggambarkan komponen sudut dan sisi pada segitigas siku-siku dengan benar. Siswa dapat menentukan sisi depan dari sudut $30^{\circ}$ dengan menggunakan konsep aturan sinus. Namun, siswa salah ketika $\frac{10}{\frac{1}{2} \sqrt{3}}=20 \sqrt{3}$ karena siswa beranggapan bahwa $\frac{1}{2} \sqrt{3}$ tidak sama dengan $\frac{\sqrt{3}}{2}$, sehingga ketika $\frac{10}{\frac{1}{2} \sqrt{3}}=10.2 \sqrt{3}=20 \sqrt{3}$. Siswa menuliskan apa yang diketahui yaitu $150 \mathrm{~cm}=1,5 \mathrm{~m}$, sehingga ketika siswa menentukan tinggi pohon cemara sama dengan 20 $\sqrt{3}$ ditambah 1,5 (jarak mata Andika dengan tanah). Oleh karena itu siswa memilih pilihan jawaban $20 \sqrt{3}+1,5$.

Siswa memilih pilihan jawaban yang salah yaitu $E$. $(20 \sqrt{3}+1,5) m$. Siswa menuliskan alasan yang salah yaitu konsep bentuk pecahan akar. Untuk tingkat keyakinan siswa yaitu 3. Tingkat keyakinan tersebut merupakan tingkat keyakinan tinggi. Dari penjelasan tersebut, pilihan jawaban salah, alasan salah, tingkat keyakinan tinggi, maka siswa dapat dikategorikan sebagai siswa yang mengalami miskonsepsi pada bentuk pecahan akar.

\section{PENUTUP}

\section{Simpulan}

Berdasarkan hasil analisis dan pembahasan diperoleh simpulan sebagai berikut. 
1. Miskonsepsi yang dialami siswa laki-laki di SMAN Kediri menggunakan Certainty of Response Index (CRI) termodifikasi yaitu pengurangan pecahan akar, mengubah informasi verbal ke bentuk visual, menentukan panjang sisi segitiga, mendefinisikan tangen, bentuk pecahan akar, menentukan sisi depan sudut, penjumlahan akar, dan mendefinisikan sinus. Akibat dari miskonsepsi tersebut menyebabkan siswa tidak dapat menentukan sisi depan, sisi samping, sisi miring pada segitiga siku-siku dengan benar, menyebabkan penalaran siswa yang salah, hasil akhir, dan tidak dapat menyelesaikan permasalahan dengan benar.

2. Miskonsepsi yang dialami siswa perempuan di SMAN Kediri menggunakan Certainty of Response Index (CRI) termodifikasi yaitu mendefinisikan tangen, mengubah informasi verbal ke bentuk visual, dan bentuk pecahan akar. Akibat dari miskonsepsi tersebut menyebabkan siswa tidak dapat menentukan sisi depan, sisi samping, sisi miring pada segitiga siku-siku dengan benar dan tidak dapat menyelesaikan permasalahan dengan benar.

\section{Saran}

1. Guru lebih menekankan pada mengubah informasi verbal ke bentuk visual, karena akibat dari miskonsepsi tersebut menyebabkan siswa tidak dapat menyelesaikan suatu permasalahan.

2. Kendala dalam penelitian yaitu ketika mengkategorikan subjek ke dalam kategori paham konsep, tidak paham konsep, ataupun miskonsepsi. Hal ini disebabkan jawaban subjek yang kurang mendetail. Ke depannya diharapkan peneliti lain tidak mengalami hal tersebut dan ditambah teknik analisis wawancara, sehingga hal tersebut dapat dihindari.

\section{DAFTAR PUSTAKA}

Gur, Hulya. 2009. "Trigonometry Learning”. New Horizons in Education. Vol. 57 (1): pp 67-80.

Hakim, Aliefman, et al. 2012. "Student Concept Understanding of natural Products Chemistry in Primary and Secondary Metabolites Using the Data Colleting Technique of Modified CRI". International Online Journal of Educational Science. Vol. 4 (3):pp 544-553.

Hasan, Saleem, et al. "Misconceptions and the Certainty of Response Index (CRI)". Pshys.Educ. Vol. 34 (5): pp 294-299.
Lampiran Peraturan Menteri Pendidikan dan Kebudayaan Nomor 59 Tahun 2014 Tentang Kurikulum 2013 Sekolah Menengah Atas/ Madrasah Aliyah.

Lampiran Peraturan Menteri Pendidikan dan Kebudayaan Nomor 21 Tahun 2016 Tentang Standar Isi Pendidikan Dasar dan Menengah.

Li, Xiaobao dan Yeping Li. 2008. "Research on Students' Misconceptions to Improve Teaching and Learning in School Mathematics and Science". Research in Brief. Vol. 108 (1): pp 4-7.

Malikha, Ziadatul dan Mohammad Faizal Amir. 2018. "Analisis Miskonsepsi Siswa Kelas V-B MIN Buduran Sidoarjo pada Materi Pecahan Ditinjau dari Kemampuan Matematika". Pi: Mathematics Education Journal. Vol. 1(2): hal. 75-81.

Mufidah, Itsna dan Mega Teguh Budiarto. 2018. “ Miskonsepsi Siswa SMP dalam Memahami Konsep Bangun Datar Segiempat Ditinjau dari Gaya Belajar VAK". Mathedunesa Jurnal Ilmiah Pendidikan Matematika. Vol. 2 (7): hal. 232-239. ISSN: 23019085.

Nugraeni, Dita, dkk. 2013. "Penyusunan Tes Diagnostik Fisika Materi Listrik Dinamis". Jurnal Pendidikan Fisika. Vol. 1 (2):hal. 12-16. ISSN: 2338-0691.

Rahim, Abdul. 2015. "Eksplorasi Kesulitan dalam Menyelesaikan Soal Cerita yang Berkaitan dengan Kelipatan Persekutuan Terkecil dan Faktor Persekutuan Terbesar Ditinjau dari Perbedaan Gender". Prosiding Seminar Nasional. Vol. 02 (1): hal. 183-190. ISSN 2443-1109.

Ramadhan, Mustafa, dkk. 2017. "Analisis Miskonsepsi Siswa dalam Menyelesaikan Soal Matematika Berstandar PISA dengan Menggunakan Certainty of Response Index (CRI)". Kadikma. Vol. (1):hal. 145153.

Sarlina. 2015. "Miskonsepsi Siswa Terhadap Pemahaman Konsep Matematika pada Pokok Bahasan Persamaan Kuadrat Siswa Kelas X5 SMA Negeri 11 Makassar". MaPan: Jurnal Matematika dan Pembelajaran. Vol. 3 (2): hal. 194-209. ISSN: 2581-172X.

Soedjadi, R. 2000. Kiat Pendidikan Matematika di Indonesia. Jakarta: Direktorat Jenderal Pendidikan Tinggi Departemen Pendidikan Nasional.

Sudijono, Anas. Pengantar Statistik Pendidikan. Jakarta: Raja Grafindo Persada.

Tadda, Marhamah. 2015. "Analisis Kesalahan Siswa dalam Menyelesaikan Soal-soal Aljabar Berdasarkan Gender". Prosiding Seminar Nasional. Vol. 02 (1): hal. 347-354. ISSN 2443-1109. 